\title{
Interference between Two Specific Pathogen Recognition Events Mediated by Distinct Plant Disease Resistance Genes
}

\author{
Claudia Ritter ${ }^{a}$ and Jeffery L. Dangl $\left.\right|^{a, b, 1}$ \\ a Max-Delbrück Laboratory, Carl-von-Linné Weg 10, 50829 Cologne, Germany \\ b Department of Biology, Coker Hall, Room 108, CB 3280, University of North Carolina, Chapel Hill, North Carolina \\ 27599-3280
}

\begin{abstract}
We demonstrate that the interaction of the avirulence gene avrRpt2 and the cognate resistance gene RPS2 interferes with the interaction of avrRpm1-RPM1 in Arabidopsis. Interference is mediated outside of the bacterial pathogen Pseudomonas syringae, presumably at the level of recognition of avr-dependent signals, yet does not require the wild-type RPS2 product. A numerical excess of $P$ syringae expressing avr $R p m 1$ can overcome this interference in mixed inoculations. The interference of avrRpt2-RPS2 engagement with RPM1-dependent functions is mirrored by transcriptional activation of genes preferentially expressed during RPM1- or RPS2-mediated disease resistance reactions. This demonstration of interference between two plant disease resistance genes suggests that their products compete for a common element(s) in a signal transduction pathway leading to disease resistance.
\end{abstract}

\section{INTRODUCTION}

Plants recognize pathogens via disease resistance $(R)$ genes, which specifically condition recognition of either the direct or indirect product of a corresponding pathogen avirulence (avr) gene. At least five Pseudomonas syringae avr genes are recognized by four unlinked Arabidopsis $R$ genes (Dangl, 1993; Kunkel, 1995). The combinations analyzed in our experiments are avrRpt2-RPS2 (Whalen et al., 1991; Innes et al., 1993; Kunkel et al., 1993; Yu et al., 1993) and avrRpm1-RPM1 (Debener et al., 1991; Dangl et al., 1992; Ritter and Dangl, 1995). The respective avr genes have never been observed to be present in the same bacterial strain. Interestingly, both avrRpm1 and avrB (Tamaki et al., 1991) are recognized by the same plant $R$ gene, $R P M 1$, although they share no sequence similarity (Bisgrove et al., 1994; Grant et al., 1995). Both RPM1 and RPS2 have recently been cloned and shown to encode related novel proteins containing a putative leucine zipper, a nucleotide binding site, and 14 imperfect leucine-rich repeats of $\sim 24$ amino acids (Bent et al., 1994; Mindrinos et al., 1994; Grant et al., 1995). Some of these features are also found in other recently cloned $R$ genes (Jones et al., 1994; Whitham et al., 1994; Lawrence et al., 1995; for reviews, see Dangl, 1995; Staskawicz et al., 1995), and this class of $R$ genes has been dubbed nucleotide binding site-LRR.

\footnotetext{
1 To whom correspondence should be addressed.
}

\begin{abstract}
It is not yet known whether these $R$ gene products bind their respective avr-specific elicitors directly, nor is their subcellular localization directly predictable from the primary amino acid sequence. The number of other plant gene products required for transduction of $R$ gene-mediated signals is also unknown, although genetic analyses in several systems have identified a handful of loci required for specific $R$ gene function (Freialdenhoven et al., 1994; Hammond-Kosack et al., 1994). In one case, the tomato Prf gene, which encodes a nucleotide binding site-LRR protein (J. Salmeron and B. Staskawicz, personal communication), is known to be required for the action of the serine-threonine kinase encoded by the Pto gene to determine resistance to strains of $P$. syringae expressing avrPto (Martin et al., 1993; Salmeron et al., 1994).
\end{abstract}

\section{RESULTS}

Conjugation of plasmids carrying either avrRpm1 or avrRpt2 into either $P$. syringae DC3000 or $P$. syringae Psm M4 (both of which cause disease on all tested Arabidopsis accessions; Debener et al., 1991; Whalen et al., 1991) results in strains triggering an idiosyncratic hypersensitive response (HR) on the Arabidopsis accession Columbia (Col-0; genotype RPM1/ RPS2; Table 1). The combination avrRpm1-RPM1 resulted in a visible $\mathrm{HR}$ at $5 \mathrm{hr}$ postinoculation, whereas the combination avrRpt2-RPS2 resulted in a weaker $\mathrm{HR}$ at $\sim 20 \mathrm{hr}$ 
Table 1. avrRpt2 Action Interferes with avrRpm1 Action in Generation of a Hypersensitive Resistance Response

\begin{tabular}{|c|c|c|c|c|c|c|}
\hline \multirow[b]{2}{*}{ HR Timing on ${ }^{a}$} & \multicolumn{6}{|c|}{ Pathogenic $P$. syringae Strain (DC3000 or Psm M4) Expressing } \\
\hline & No avr Gene & avrRpm1 & avrRpt2 & $\begin{array}{l}\text { avrRpm1 } \\
+ \\
\text { avrRpt2 }\end{array}$ & $\begin{array}{l}\text { avrRpm1 } \\
+ \\
\text { avrRpt2:: } \Omega\end{array}$ & $\operatorname{Mix}^{b}$ \\
\hline RPM1/RPS2 & - & $+5 \mathrm{hr}$ & $+21 \mathrm{hr}$ & $+21 \mathrm{hr}$ & $+5 \mathrm{hr}$ & $+21 \mathrm{hr}$ \\
\hline RPM1/rps2 & - & $+5 \mathrm{hr}$ & - & - & $+5 \mathrm{hr}$ & - \\
\hline$r p m 1^{\text {null } / R P S 2^{c}}$ & - & - & $+6 \mathrm{hr}$ & $+6 \mathrm{hr}$ & - & $+6 \mathrm{hr}$ \\
\hline
\end{tabular}

Bacteria were prepared and inoculated as described by Ritter and Dangl (1995) at an initial inoculum density of $5 \times 10^{7}$ colony-forming units (cfu)/mL. Tissue collapse indicative of HR was monitored visually. Each combination of $P$. syringae and Arabidopsis was tested in more than six experiments on a minimum of four individual plants ( 16 to 20 total leaves) per experiment. Data for expressing both avr genes simultaneously are from experiments using pCR105. A minus (-) indicates lack of recognition; a plus (+) followed by timing in hours (hr) indicates HR on all leaves assayed.

a Plant genotypes are described in the text.

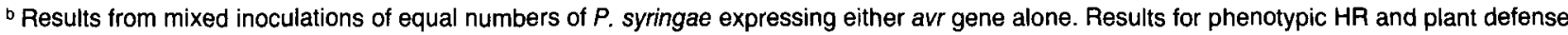
gene induction in mix inoculations with titration are displayed in Figures 3 to 5 .

c Accession Nd-0.

postinoculation. We examined these two sets of specific interactions simultaneously by constructing $P$. syringae strains that carried both avrRpm1 and avrRpt2 cloned either into the same replicon or into two compatible replicons (Ritter and Dangl, 1995; see Methods) or by performing mixed inoculations of $P$. syringae expressing either avrRpm1 or avrRpt2 (again both DC3000 and Psm M4 transconjugants were tested). We expected that each avr- $R$ gene combination would act independently, the rapid $\mathrm{HR}$ of accession Col-0 in response to avrRpm1 would be observed, and the slower response to avrRpt2 would be masked (Table 1).

In fact, strains expressing both avr genes triggered HR on either accession indicative only of the avrRpt2-RPS2 interaction, including the slower reaction on Col-0, in repeated experiments (Table 1). These results initially suggested that expression of wild-type avrRpt2 and, potentially, functional engagement of RPS2 interfered with the avrRpm1-RPM1 interaction. Several trivial explanations for this observation were ruled out by testing vector and copy number effects in four ways. First, we recovered nearly identical bacterial counts from leaves inoculated with $P$. syringae carrying both avr genes on separate vectors (plating for different antibiotic resistance markers present on either avr gene vector). These samples were harvested at $5 \mathrm{hr}$ postinoculation, which is the expected timing for an HR caused by the avrRpm1-RPM1 combination. These titrations (data not shown) demonstrated that the bacteria expressing avrRpt2 did not kill or inhibit growth of those expressing avrRpm1 and showed that the plasmid expressing avrRpm1 is not selectively lost from bacteria carrying both replicons. Second, both avr genes were cloned into a single vector called pCR105 (Ritter and Dangl, 1995; see Methods), and the interference of the avrRpt2-RPS2 combination with avrRpm1-RPM1 was still observed. Third, a compatible replicon carrying avrRpt2 with its open reading frame disrupted by insertion of the $\operatorname{Tn} 5 \Omega$ (Whalen et al., 1991) was introduced into $P$. syringae DC3000 carrying avrRpm1. In this case, tim- ing of the HR indicative of the avrRpm1-RPM1 interaction was restored. Fourth, we used RNA gel blot analysis to show that expression of avrRpt2 did not influence expression of avrRpm1. We grew $P$. syringae DC3000 carrying these avr genes either singly or in combination in bacterial culture conditions known to induce avr gene transcription, prepared RNA gel blots, and observed no significant difference in transcript levels (data not shown; see Methods).

Table 1 shows the results of inoculation experiments assessing timing of the HR. The rps2-201 mutant (a point mutation leading to an amino acid exchange in the LRR region; Bent et al., 1994) did not recognize $P$. syringae expressing both avr genes, even though RPM 1 is functional in these plants. More importantly, mixed inoculations of $P$. syringae expressing either avrRpm1 or avrRpt2 singly (in equal numbers) onto either wild-type Col-0 or rps2 plants also did not trigger the rapid HR indicative of the avrRpm1-RPM1 interaction. This result demonstrated that the observed interference is manifested outside the bacteria. Increasing the ratio of bacteria expressing avrRpm1 in the mixed inoculations, however, restored the rapid RPM1-mediated HR (detailed below).

In the absence of recognition, $P$. syringae DC3000 expressing both avr genes was capable of sustained growth in leaves of rps2 plants, although these plants still expressed a functional RPM1 gene. These analyses are presented in Figure 1 for inoculations of all strains onto leaves of either wild-type Col-0 (RPM1/RPS2), a Col-0-derived rps2 mutant, and the naturally occurring rpm ${ }^{\text {null }} / R P S 2$ accession $\mathrm{Nd}-0$. As expected, each strain carrying a functional avr gene was incapable of sustained growth on wild-type Col-O (Figure 1A). After inoculation into leaves of the rps 2 mutant, the strain expressing only avrRpt2 grew, due to the rps2 mutation (Figure 1B). Importantly, the strain expressing both avrRpt2 and avrRpm1 (either cloned together on the pCR105 vector or present on compatible replicons) also grew on the rps2 mutant. The growth of each strain in the accession Nd-O (Figure $1 \mathrm{C}$ ) served as a specificity con- 
trol for each gene-for-gene interaction. We also observed this interference when a strain expressing avrB was substituted for those expressing avrRpm1 in mixed inocula (data not shown). Together, data presented in Table 1 and Figure 1 strongly suggest that an avrRpt2-dependent signal, acting outside the bacterial pathogen, precludes the triggering of resistance responses indicative of the avrRpm1-RPM1 combination. Moreover, this interference does not require a wild-type RPS2 product.

We sought further evidence for functional interference of the avrRpt2-RPS2 pathway over that determined by avrRpm1-RPM1 by analyzing $R$ gene-mediated, induced expression of plant defense genes. The $E L / 3$ gene encodes a protein highly related, but not identical, to cinnamyl alcohol dehydrogenases. Its transcription is rapidly induced in an RPM1-dependent manner and is not induced in RPS2-mediated interactions (Kiedrowski et al., 1992). We harvested total RNA following mixed inoculations of either Col-0 or rps2 mutant plants at $4 \mathrm{hr}$ postinoculation. We also titrated increasing quantities of $P$. syringae expressing only avrRpm1 into the mixed inoculum to determine whether both the typical RPM1 HR at
$5 \mathrm{hr}$ and $R P M 1$-mediated EL/3 expression could be restored. The RNA blot analysis displayed in Figure 2 demonstrates several points. First, relatively low levels of $P$. syringae expressing avrRpm1 are sufficient for both rapid $\mathrm{HR}$ at $5 \mathrm{hr}$ and maximal EL/3 expression. Second, a mixed inoculum with a 2.5-fold input excess of $P$. syringae expressing avrRpm1 can restore both the rapid $R P M 1$-mediated $H R$ and maximal EL/3 expression. This ratio is apparently at the threshold for such restoration, because in this particular experiment, RPM1-mediated HR and ELI3 expression are restored only in Col-0 plants (see below). Third, in mixed inoculations in which avrRpt2-dependent interference was observed (no RPM1-dependent HR at $5 \mathrm{hr}$ ), only background levels of EL/3 expression were found in either wild-type Col-0 or rps2 mutant plants. Fourth, a wild-type RPS2 protein was not required for interference, as neither the rapid RPM1-dependent HR nor induced levels of EL/3 expression were observed in mixed inocula of an rps2 mutant. Note that in all cases in which interference was observed, the absolute number of bacteria expressing avrRpm1 in the mixed inocula was sufficient to trigger maximal $E L / 3$ induction when inoculated alone.
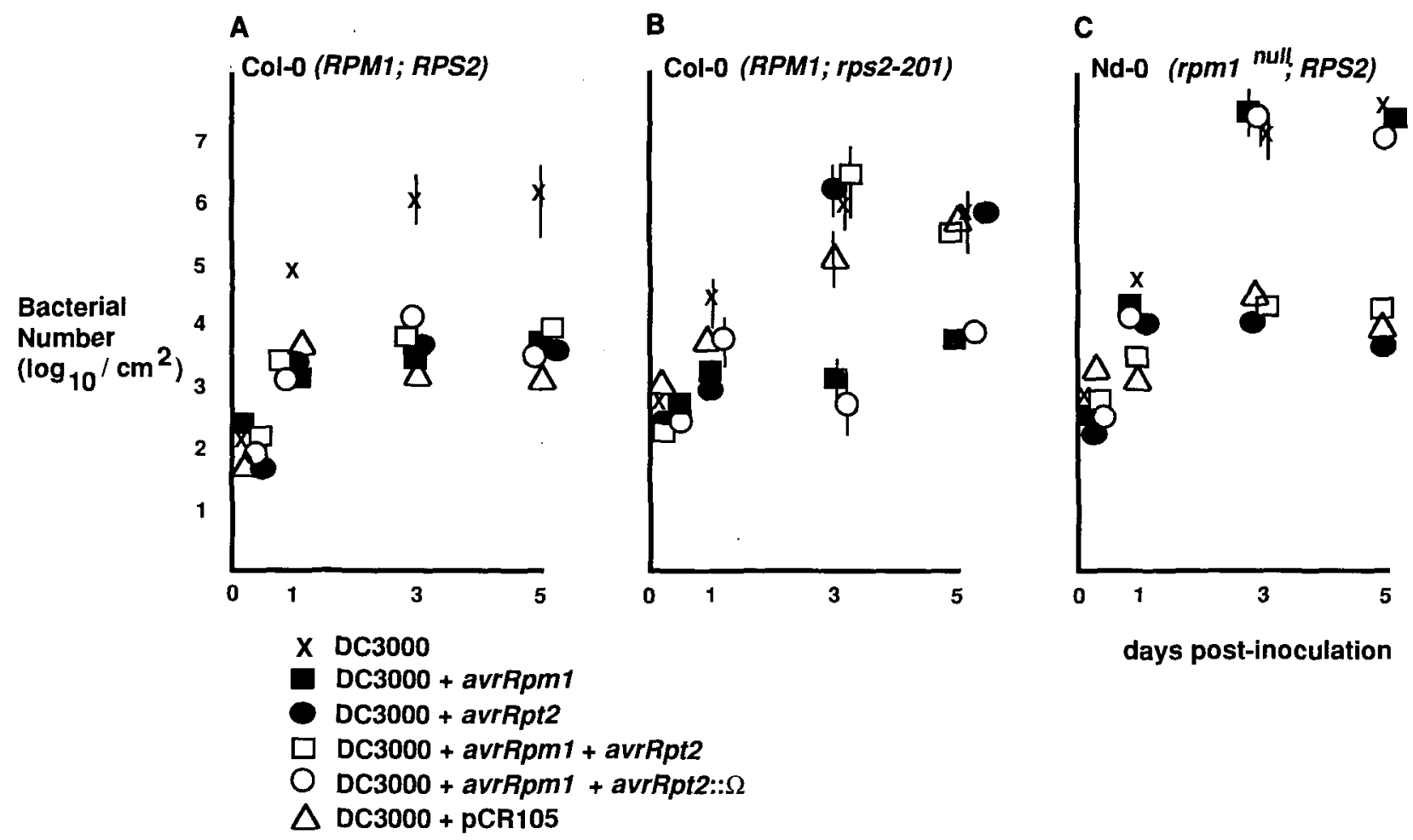

Figure 1. Growth of $P$. syringae DC3000 Carrying either avrRpm1 or avrRpt2 Singly, or Both Genes Together, in Arabidopsis Leaves.

(A) to (C) Bacteria were grown and prepared for inoculation, as described by Ritter and Dangl (1995), and inoculated into leaves of adult, 5-weekold Arabidopsis plants ( $R$ gene compositions are given in [A] to [C]) at an initial concentration of $10^{5} \mathrm{cfu} / \mathrm{mL}$. Leaves were harvested at the indicated time points, ground in $10 \mathrm{mM} \mathrm{MgCl}_{2}$, and titrated on media selective for markers on the bacterial chromosome and each vector as described by Ritter and Dangl (1995; see Methods). Each data point represents the mean of three to eight independent experiments, and duplicates of four leaves each were harvested within an experiment. Standard deviation is presented where it was larger than the symbols. 
Psm M4 expressing:

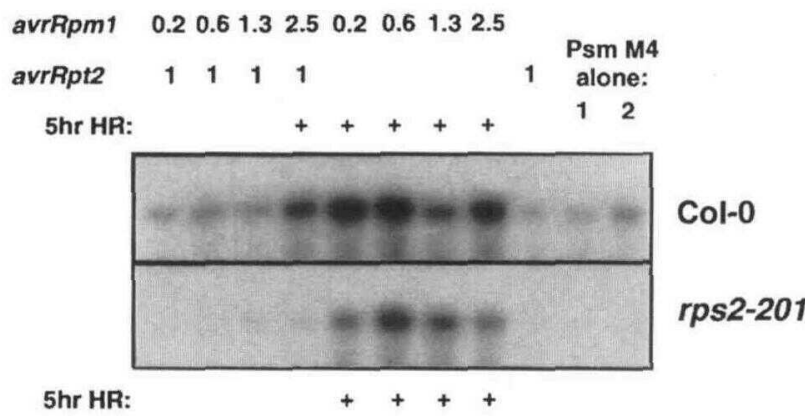

Figure 2. Mixed Inocula Result in Interference with RPM1-Dependent Induction of EL/3 Expression.

Two $P$. syringae Psm M4 transconjugants independently expressing either avrRpm1 or avrRpt2 from the pL6 vector were inoculated onto leaves of Col-0 or rps2-201 plants either alone or after mixing the input amounts indicated ( 1 represents an initial concentration of $5 \times$ $10^{7} \mathrm{cfu} / \mathrm{mL}$ ) to achieve various ratios of bacteria expressing each avr gene in an inoculum containing at least $5 \times 10^{7} / \mathrm{mL}$ total bacteria. Note restoration of the RPM1-dependent HR and EL/3 induction in Col-0 at an input ratio of 2.5:1. RNA was harvested at $4 \mathrm{hr}$ postinoculation and prepared as described in Methods. The probe was an EL/3 fulllength CDNA (Kiedrowski et al., 1992). A (+) indicates visible tissue collapse at $5 \mathrm{hr}$ postinoculation in the remaining inoculated leaves.

In addition to data presented in Figure 2, we performed mixed inocula of wild-type Col-0 and the rps2 mutant with a second $P$. syringae strain, DC 3000 , in which avrRpm1 and avrRpt2 were expressed from vectors carrying different antibiotic markers on different replicons (pVSP61 for avrRpm1 and pL6 for avrRpt2; see Methods). This allowed determination of absolute numbers of bacterial cells in the leaves at the time of harvest for RNA preparation. In repeated experiments using either $P$. syringae strain, we observed restoration of RPM1-dependent HR and $E L / 3$ induction in Col- 0 and the rps 2 mutant at a ratio of $\sim 4: 1$ or higher. Maximal levels of EL/3 expression triggered when delivering avrRpm1 signal from DC3000 were repeatedly lower than those observed using Psm M4 (data not shown).

We controlled for the occurrence of RPS2-mediated signal transduction in mixed inocula in which interference was observed by utilizing the AIG1 (for avrRpt2-induced gene) clone described by Reuber and Ausubel (1996). AlG1 encodes a novel protein that displays an expression mode opposite to that of ELI3; namely, it is induced during RPS2-mediated resistance reactions but not during RPM1-mediated interactions. The RNA gel blot analysis displayed in Figure 3 demonstrates that A/G1 expression is observed in those mixed inoculations in which both a rapid RPM1-mediated HR and EL/3 induction were suppressed but an HR at $22 \mathrm{hr}$ postinoculation was visible. Interestingly, inoculation with low absolute doses of bacteria expressing only avrRpm1 led to some AIG1 induction in some, but not all, experiments. This induction disappeared as the absolute dose of avrRpm1-expressing bacteria was increased. Figure 3 also demonstrates the specificity of A/G1 induction, using the accession Nd-0 (genotype rpm1null/RPS2). We also confirmed that $A / G 1$ is not induced in rps2 mutants (data not shown; see Reuber and Ausubel, 1996). Thus, the interference with avrRpm1-RPM1-dependent signaling we observed is accompanied by induction of RPS2-mediated gene induction.

\section{DISCUSSION}

Our results clearly demonstrate interference of one gene-forgene interaction over another. We report two novel findings: first, interference of the avrRpt2-RPS2 interaction with the avrRpm1-RPM1 interaction occurs outside of the two pathogenic $P$. syringae strains used in this study; and second, this interference does not require wild-type RPS2 protein.

More than $15 P$. syringae avr genes have been cloned over the last decade, and each triggers resistance in appropriate plant lines expressing the corresponding $R$ gene (Staskawicz et al., 1984; Dangl, 1994). The role of avr genes in initiating $R$ gene action remains enigmatic. In addition to avr genes, several examples exist of genetically defined inhibitors of avr gene action in both phytopathogenic fungi and bacteria (Lawrence et al., 1981; Christ and Groth, 1982; Crute, 1985; llott et al.,

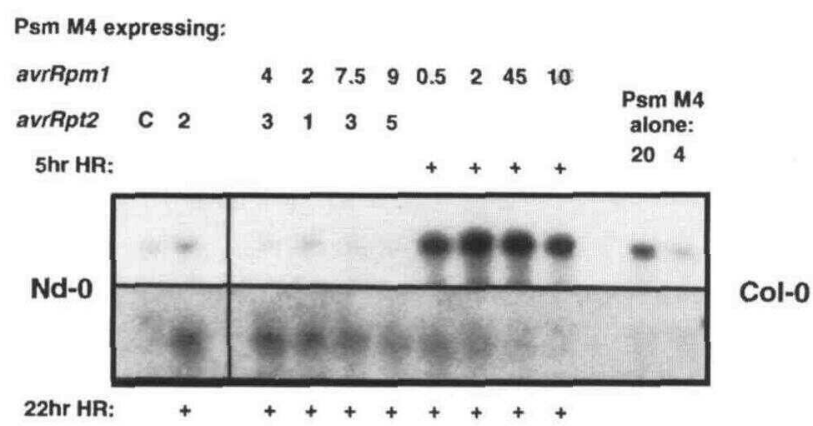

Figure 3. Interference with avrRpm1-RPM1 Signaling Is Accompanied by Induction of AlG1 Expression.

avr genes were independently expressed in two transconjugants of Psm M4 on different replicons (pVSP61 for avrRpm1 and pL6 for avrRpt2). At $4 \mathrm{hr}$ postinoculation, leaf samples were taken for RNA preparation and for titration. Additional inoculated leaves were observed for an $\mathrm{HR}$ at 5 and $22 \mathrm{hr}$ postinoculation. Because the two vectors carry different antibiotic markers, numbers (1 represents $5 \times 10^{5}$ $\mathrm{cfu} / \mathrm{cm}^{2}$ ) reflect titers and ratios of each bacteria in leaves at the time of harvest. The autoradiograph at top is from a blot hybridized with EL/3 CDNA, as described in the Figure 2 legend. The filter was stripped and reprobed with the AIG1 cDNA described by Reuber and Ausubel (1996). RNA from leaves of accession Nd-0 ( $R$ genotype rpm $1^{\text {null/ }}$ RPS2; separated by vertical black line at left) either inoculated with Psm M4 alone (control, labeled C) or expressing avrRpt2 provides a specificity control for gene induction. 
A

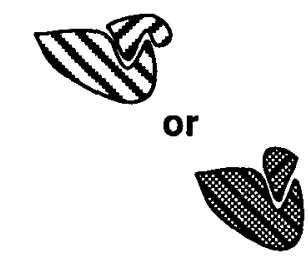

B
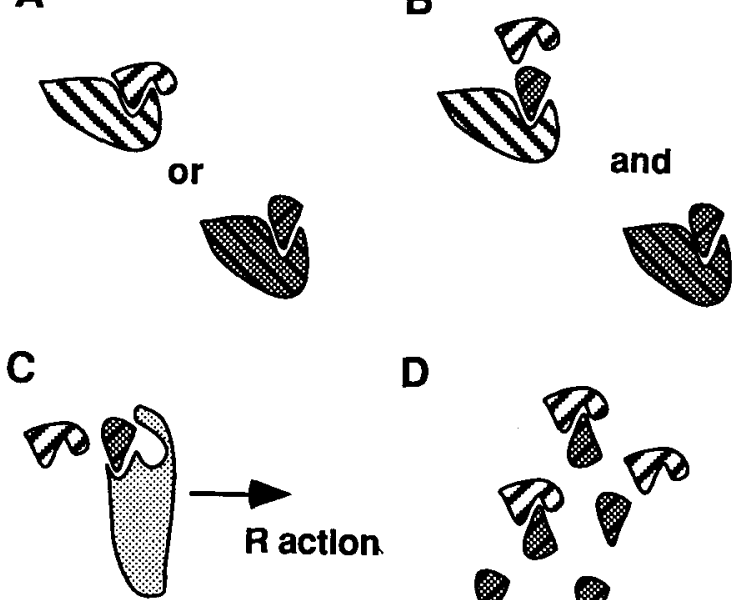

$\mathbf{D}$

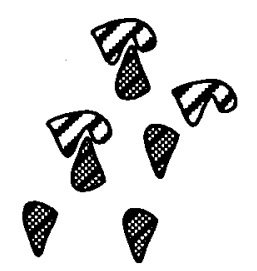

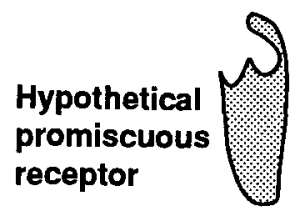

avrRpt2 RPS2

Figure 4. General Hypothetical Models to Explain $R$ Gene Interference.

Each symbol is described at the bottom of the figure. See text for details. (A) The independent interaction of each avr-derived signal with its cognate $R$ gene product.

(B) and (C) Models whereby one avr-derived signal competes with the other for binding to either the cognate $R$ gene products or a more general promiscuous receptor.

(D) A model of direct interference of one avr-derived signal with another.

1989; Lau et al., 1993). One theory is that $P$. syringae avr genes are enzymes whose action leads to the biosynthesis of a specific elicitor, which is recognized by the corresponding plant $R$ gene. This scenario is supported by analysis of the avrD gene, whose product dictates production of a specific elicitor (Keen et al., 1990; Midland et al., 1993). There is no evidence that avr gene products are secreted or that any purified avrencoded protein elicits $R$ gene-dependent resistance, although this possibility is suggested by analysis of fungal avr gene products produced by extracellular pathogens (Van der Ackerveken et al., 1992; Joosten et al., 1994; Rohe et al., 1995). Biochemical characterization of putative avr gene-specific elicitors has proven extremely difficult, suggesting that these elicitors are present in vanishingly small quantities or are unstable.

Several general models, outlined in Figure 4, explain our findings that avrRpt2 is functionally epistatic to avrRpm 1 in a manner independent of wild-type RPS2 protein and occurring outside the bacteria. If the RPM1 and RPS2 proteins do bind their respective avr-dependent signals directly, as depicted for

each wild-type interaction in Figure 4A, it may be that the avrRpt2-derived signal can also bind to RPM1 in a manner precluding its activity (Figure $4 B$ ). This putative interaction could result in shunting of more signal down the RPS2dependent pathway and could serve to enhance resistanceresponse specificity. This model is also consistent with our titration data, especially if the binding of the avrRpt2-derived signal to RPM1 is of low affinity. In the rps2 mutant, the avrRpt2derived signal could still bind the RPS2 protein but in a nonproductive manner. This model is also consistent with data from Reuber and Ausubel (1996), which show that $R$ gene interference can, under some circumstances, work in either direction. (Differences in our observations can most likely be ascribed to slight differences in experimental conditions or vectors employed to deliver avr signals, and the sum of our data indicates a fine tuning of these signaling systems.) Alternatively, it could be that the avr-dependent signal molecules do not bind to either RPM1 or RPS2 proteins but rather to a common element required for $R$ gene action (the hypothetical promiscuous receptor in Figure 4C). Our ability to titrate the observed interference is also consistent with the idea that avr-derived signals may compete for a common binding site on a molecule required to trigger $R$ gene function. A possible candidate is the gene defined by the ndr1 mutation, whose action is required for appropriate function of several Arabidopsis $R$ genes (Century et al., 1995).

It is also possible that the avrRpt2-derived signal directly inhibits action of the avrRpm1-derived signal, as shown in Figure 4D. In this case, the putative avrRpt2 elicitor could bind the avrRpm1 elicitor, titrating its activity and allowing excess avrRpt2 elicitor to still act, as depicted in Figure 4D. If the avr gene products encode enzymes active outside the bacteria, then this scenario would also be plausible and would suggest that avrRpt2 is biochemically epistatic to avrRpm1. This latter notion is based broadly on biosynthesis of host plant-specific Nod factors. These substituted lipo-oligochitin molecules are required to initiate the series of plant responses required for successful symbiotic colonization of plant roots by various Rhizobium species (Dénarié and Cullimore, 1993; Long and Staskawicz, 1993; Schultze et al., 1994). If the avr-derived elicitors did share a common structural component, one can-

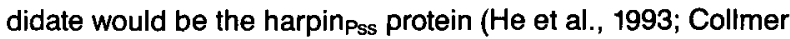
and Bauer, 1994; Preston et al., 1995), which is sufficient to trigger nonhost HR in several species. This model would then further suggest that avr genes encode enzymes that modify or act in concert with the harpin protein outside of the bacterial cell. Because harpin is also a general pathogenicity factor, avr gene-modified harpins could also serve as host-specific pathogenicity factors. The recent finding that several $P$. syringae avr genes, including avrRpm1, are required for maximal pathogenicity supports this idea (Dangl, 1994; Lorang et al., 1994; Ritter and Dangl, 1995).

The availability of cloned $R$ genes and avr genes in isogenic settings for both host and pathogen and of genes induced in an interaction-specific manner will spur future developments aimed at a molecular resolution of these models. 


\section{METHODS}

\section{Bacterial Strains and Plasmids}

Most bacterial strains and plasmids have been described by Ritter and Dangl (1995), Dangl et al. (1992), and Debener et al. (1991). From Ritter and Dangl (1995), we used pCR106, which is pL6 carrying avrRpm1. For these experiments, several new vectors expressing avirulence (avr) genes were constructed: pCR107 is pL6 with the HindIII fragment carrying avrRpt2 from pABL18 (Whalen et al., 1991) cloned into the vector HIndll site. pCR104 carries avrRpmt in pLAFR5. We constructed pCR105 from pCR104 by subcloning the same Hindlll fragment containing avrRpt2 into the available Hindll site. pCR105 thus expresses both avr genes. A pVSP61 derivative carrying avrRpm7 was provided by Roger Innes (Indiana University, Bloomington). pLAFR and $\mathrm{pL} 6$ derivatives encode tetracycline resistance, and $\mathrm{pVSP}$ derivatives encode kanamycin resistance. Transconjugants described in the text were constructed as given by Ritter and Dangl (1995). Expression of each avr gene in these transconjugants was controlled by RNA blot analysis, using bacterial culture conditions known to induce avr gene expression (Ritter and Dangl, 1995). We used polymerase chain reaction-amplified fragments as probes (Ritter and Dangl, 1995) for RNA blots, which demonstrated that each avr gene on pCR106 was expressed in roughly equivalent amounts and that each avr gene when carried separately was also expressed.

Plant Care and Inoculations

All inoculations and growth curves were performed as described by Ritter and Dangl (1995).

\section{RNA Gel Blot Analysis}

RNA was extracted from leaves inoculated with bacteria or with buffer as a control and prepared and blotted as described by Kiedrowski et al. (1992). The EL/3 and A/G1 probes were gel-isolated inserts labeled by using a random priming kit (Boehringer Mannheim). An actin probe was used to check for equal loading in all experiments (data not shown). RNA was harvested from six plants per experimental treatment, and blots shown are indicative of two to four independent RNA experiments.

\section{ACKNOWLEDGMENTS}

This work was supported by grants to J.L.D. from the German Research Society (DFG) Focus Program in Molecular Phytopathology and from the German Federal Ministry of Research and Technology (BMFT). We thank Roger Innes, and Doug Dahlbeck and Brian Staskawicz (University of California, Berkeley) for providing strains and plasmids. We are also grateful to Wolfgang "Dude" Knogge (Max Planck Institute, Cologne, Germany) for discussions and critical reading of the manuscript. We thank Udo Ringeisen (Cologne) and Susan Whitfield (Chapel Hill, NC) for help in preparing the figures.

Received August 23, 1995; accepted November 22, 1995.

\section{REFERENCES}

Bent, A.F., Kunkel, B.N., Dahlbeck, D., Brown, K.L., Schmidt, R., Giraudat, J., Leung, J., and Staskawicz, B.J. (1994). RPS2 of Arabidopsis thaliana: A leucine-rich repeat class of plant disease resistance genes. Science 265, 1856-1860.

Bisgrove, S.R., Simonich, M.T., Smith, N.M., Sattler, N.M., and Innes, R.W. (1994). A disease resistance gene in Arabidopsis with specificity for two different pathogen avirulence genes. Plant Cell 6, 927-933.

Century, K.S., Holub, E.B., and Staskawicz, B.J. (1995). NDR1, a locus of Arabidopsis thaliana that is required for disease resistance to both a bacterial and a fungal pathogen. Proc. Natl. Acad. Sci. USA 92, 6597-6601.

Christ, B.J., and Groth, J.V. (1982). Inheritance of virulence to three bean cultivars in three isolates of the bean rust pathogen. Phytopathology 72, 767-770.

Collmer, A., and Bauer, D.W. (1994). Enwinia chyrsanthemi and Pseudomonas syringae: Plant pathogens trafficking in extracellular virulence proteins. In Bacterial Pathogenesis of Plants and Animals: Molecular and Cellular Mechanisms, J.L. Dangl, ed (Heidelberg: Springer-Verlag), pp. 43-78.

Crute, I.R. (1985). The genetic bases of relationships between microbial parasites and their hosts. In Mechanisms of Resistance to Plant Diseases, R.S.S. Fraser, ed (Dordrecht, The Netherlands: Kluwer Academic Publishers), pp. 80-143.

Dangl, J.L. (1993). The emergence of Arabidopsis thaliana as a model for plant-pathogen interactions. Adv. Plant Pathol. 10, 127-155.

Dangl, J.L. (1994). The enigmatic avirulence genes of phytopathogenic bacteria. In Bacterial Pathogenesis of Plants and Animals: Molecular and Cellular Mechanisms, J.L. Dangl, ed (Heidelberg: Springer-Verlag), pp. 99-118.

Dangl, J.L. (1995). Pièce de résistance: Novel classes of plant disease resistance genes. Cell 80, 363-366.

Dangl, J.L., Ritter, C., Gibbon, M.J., Wood, J.R., Mur, L.A.J., Goss, S., Mansfield, J.W., Taylor, J.D., and Vivian, A. (1992). Functional homologs of the Arabidopsis RPM1 disease resistance gene in bean and pea. Plant Cell 4, 1359-1369.

Debener, T., Lehnackers, H., Arnold, M., and Dangl, J.L. (1991). Identification and molecular mapping of a single Arabidopsis thaliana locus determining resistance to a phytopathogenic Pseudomonas syringae isolate. Plant J. 1, 289-302.

Dénarié, J., and Cullimore, J. (1993). Lipo-oligosaccharide nodulation factors: A new class of signaling molecules mediating recognition and morphogenesis. Cell 74, 951-954.

Freialdenhoven, A., Scherag, B., Hollricher, K., Collinge, D., Christensen, H.-T., and Schulze-Lefert, P. (1994). Nar-1 and Nar-2, two loci required for Mla-12-specified race resistance to powdery mildew in barley. Plant Cell 6, 983-994.

Grant, M.R., Godiard, L., Straube, E., Ashfield, T., Lewald, J., Sattler, A., Innes, R.W., and Dangl, J.L. (1995). Structure of the Arabidopsis RPM1 gene enabling dual specificity disease resistance. Science 269, 843-846.

Hammond-Kosack, K.E., Jones, D.A., and Jones, J.D.G. (1994). Identification of two genes required in tomato for full $\mathrm{Cf}$-9-dependent resistance to Cladosporium fulvum. Plant Cell 6, 361-374.

He, S.Y., Huang, H.-C., and Collmer, A. (1993). Pseudomonas syrin-

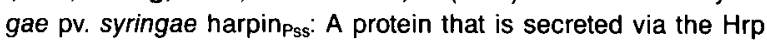


pathway and elicits the hypersensitive response in plants. Cell 73 , 1255-1266.

Ilott, T.W., Hulbert, S.H., and Michelmore, R.W. (1989). Genetic anal$y$ yis of the gene-for-gene interaction between lettuce (Lactuca sativa) and Bremia lactucae. Phytopathology 79, 888-897.

Innes, R.W., Bent, A.F., Kunkel, B.N., Bisgrove, S.R., and Staskawicz, B.J. (1993). Molecular analysis of avirulence gene avrRpt2 and identification of a putative regulatory sequence common to all known Pseudomonas syringae avirulence genes. J. Bacteriol. 175, 4859-4869.

Jones, D.A., Thomas, C.M., Hammond-Kosack, K.E., Balint-Kurti, P.J., and Jones, J.D.G. (1994). Isolation of the tomato Cf-9 gene for resistance to Cladosporium fulvum by transposon tagging. Science 266, 789-793.

Joosten, M.H.A.J., Cozijnsen, T.J., and De Wit, P.J.G.M. (1994). Host resistance to a fungal tomato pathogen lost by a single base-pair change in an avirulence gene. Nature 367, 384-386.

Keen, N.T., Tamaki, S., Kobayashi, D., Gerhold, D., Stayton, M., Shen, H., Gold, S., Lorang, J., Thordal-Christenson, H., Dahlbeck, D., and Staskawicz, B.J. (1990). Bacteria expressing avirulence gene $D$ produce a specific elicitor of the soybean hypersensitive reaction. Mol. Plant-Microbe Interact. 3, 112-121.

Kiedrowski, S., Kawalleck, P., Hahlbrock, K., Somssich, I.E., and Dangl, J.L. (1992). Rapid activation of a novel plant defense gene is strictly dependent on the Arabidopsis RPM1 resistance locus. EMBO J. 11, 4677-4684.

Kunkel, B.N. (1995). A useful weed put to work: Genetic analysis of disease resistance in Arabidopsis thaliana. Trends Genet., in press.

Kunkel, B.N., Bent, A.F., Dahlbeck, D., Innes, R.W., and Staskawicz, B.J. (1993). RPS2, an Arabidopsis disease resistance locus specifying recognition of Pseudomonas syringae strains expressing the avirulence gene avrRpt2. Plant Cell 5, 865-875.

Lau, G.W., Chao, C.T., and Ellingboe, A.H. (1993). Interaction of genes controlling avirulence/virulence of Magnaporthe grisea on rice cultivar Katy. Phytopathology 83, 375-382.

Lawrence, G.J., Mayo, G.M.E., and Shepherd, K.W. (1981). Interactions between genes controlling pathogenicity in the flax rust fungus. Phytopathology 71, 12-19.

Lawrence, G.J., Finnegan, E.J., Ayliffe, M.A., and Ellis, J.G. (1995). The $L 6$ gene for flax rust resistance is related to the Arabidopsis bacterial resistance gene RPS2 and the tobacco viral resistance gene N. Plant Cell 7, 1195-1206.

Long, S.R., and Staskawicz, B.J. (1993). Prokaryotic plant parasites. Cell 73, 921-935.

Lorang, J.M., Shen, H., Kobayashi, D., Cooksey, D., and Keen, N.T. (1994). avrA and avrE in Pseudomonas syringae pv. tomato PT23 play a role in virulence on tomato plants. Mol. Plant-Microbe Interact. 7, 208-215.

Martin, G.B., Brommonschenkel, S.H., Chunwongse, J., Frary, A., Ganal, M.W., Spivey, R., Wu, T., Earle, E.D., and Tanksley, S.D. (1993). Map-based cloning of a protein kinase gene conferring disease resistance in tomato. Science 262, 1432-1436.

Midland, S.L., Keen, N.T., Sims, J.J., Midland, M.M., Stayton, M.M., Burton, V., Graham, K.J., and Clardy, J. (1993). The structures of syringolides 1 and 2, novel C-glucosidic elicitors from Pseudomonas syringae pv. tomato. J. Org. Chem. 58, 2940-2945.

Mindrinos, M., Katagiri, F., Yu, G.-L., and Ausubel, F.M. (1994). The A. thaliana disease resistance gene RPS2 encodes a protein containing a nucleotide-binding site and leucine-rich repeats. Cell $\mathbf{7 8}$, 1089-1099.

Preston, G., Huang, H.-C., He, S.Y., and Collmer, A. (1995). The hrpZ proteins of Pseudomonas syringae pv. syringae, glycinea, and tomato are encoded by an operon containing yersinia ysc homologs and elicit the hypersensitive response in tomato but not in soybean. Mol. Plant-Microbe Interact. 8, 717-732.

Reuber, T.L., and Ausubel, F.M. (1996). Isolation of Arabidopsis genes that differentiate between resistance responses mediated by the RPS2 and RPM1 disease resistance genes. Plant Cell 8, 241-249.

Ritter, C., and Dangl, J.L. (1995). The Pseudomonas syringae pv. maculicola avrRpm1 gene is required for virulence on Arabidopsis. Mol. Plant-Microbe Interact. 8, 444-453.

Rohe, M., Gierlich, A., Hermann, H., Hahn, M., Schmidt, B., Rosahl, S., and Knogge, W. (1995). The race-specific elicitor, NIP1, from the barley pathogen, Rhynchosporium secalis, determines avirulence on host plants of the Rrs1 resistance genotype. EMBO J. 14, 4168-4177.

Salmeron, J.M., Barker, S.J., Carland, F.M., Mehta, A.Y., and Staskawicz, B.J. (1994). Tomato mutants altered in bacterial disease resistance provide evidence for a new locus controlling pathogen recognition. Plant Cell 6, 511-520.

Schultze, M., Kondorosi, E., Ratet, P., Buire, M., and Kondorosi, A. (1994). Cell and molecular biology of Rhizobium-plant interactions. Int. Rev. Cytol. 156, 1-75.

Staskawicz, B.J., Dahlbeck, D., and Keen, N. (1984). Cloned avirulence gene of Pseudomonas syringae pv. glycinea determines race-specific incompatibility on G/ycine max (L.) Merr. Proc. Natl. Acad. Sci. USA 81, 6024-6028.

Staskawicz, B.J., Ausubel, F.M., Baker, B.J., Ellis, J., and Jones, J.D.G. (1995). Molecular genetics of plant disease resistance. Science 268, 661-667.

Tamaki, S.J., Kobayashi, D.Y., and Keen, N.T. (1991). Sequence domains required for the activity of avirulence genes avrB and avrC from Pseudomonas syringae pv. glycinea. J. Bacteriol. 173, 301-307.

Van der Ackerveken, G.F.J.M., Van Kan, J.A.L., and De Wit, P.J.G.M. (1992). Molecular analysis of the avirulence gene avr9 of the fungal tomato pathogen Cladosporium fulvum fully supports the gene-forgene hypothesis. Plant J. 2, 359-366.

Whalen, M.C., Innes, R.W., Bent, A.F., and Staskawicz, B.J. (1991) Identification of Pseudomonas syringae pathogens of Arabidopsis and a bacterial locus determining avirulence on both Arabidopsis and soybean. Plant Cell 3, 49-59.

Whitham, S., Dinesh-Kumar, S.P., Choi, D., Hehl, R., Corr, C., and Baker, B. (1994). The product of the tobacco mosaic virus resistance gene $N$ : Similarity to Toll and the interleukin-1 receptor. Cell $\mathbf{7 8}$, 1101-1115

Yu, G.-L., Katagiri, F., and Ausubel, F.M. (1993). Arabidopsis mutations at the RPS2 locus result in loss of resistance to Pseudomonas syringae strains expressing the avirulence gene avrRpt2. Mol. PlantMicrobe Interact. 6, 434-443. 
Interference between Two Specific Pathogen Recognition Events Mediated by Distinct Plant Disease Resistance Genes.

C. Ritter and J. L. Dangl

Plant Cell 1996;8;251-257

DOI 10.1105/tpc.8.2.251

This information is current as of July 22, 2020

Permissions

eTOCs

CiteTrack Alerts

Subscription Information
https://www.copyright.com/ccc/openurl.do?sid=pd_hw1532298X\&issn=1532298X\&WT.mc_id=pd_hw153229 $8 \mathrm{X}$

Sign up for eTOCs at:

http://www.plantcell.org/cgi/alerts/ctmain

Sign up for CiteTrack Alerts at:

http://www.plantcell.org/cgi/alerts/ctmain

Subscription Information for The Plant Cell and Plant Physiology is available at: http://www.aspb.org/publications/subscriptions.cfm 